\title{
RED-BREASTED NUTHATCHES NEST AT BRANDON, MANITOBA
}

MAMIE MCCOWAN, 1415-8 Street, Brandon, Manitoba. R7A $3 Z 6$

Two Red-breasted Nuthatches spent the winter of 1987-1988 in or close to the yard of my next-door neighbors $\mathrm{Mr}$. and Mrs. B.A. Robinson. There is a shelterbelt of at least 30 mature spruce and pine trees on that property and Mrs. Robinson operates a bird-feeding station.

On 15 April 1988 a Red-breasted Nuthatch was heard tapping on the trunk of an old Manitoba Maple on the boulevard. The top of this tree had broken off in a windstorm a few years ago. The following day two nuthatches were seen there, one starting to make a cavity, the other nearby. The two birds appeared to take turns working and were seen as early as
7 a.m. and as late as $8: 45$ p.m. They started three holes. On 30 April a nuthatch was seen working at the middle hole about $5 \mathrm{~m}$ from the ground; here the nesting was carried on. By 6 May wood chips about dime-sized were being thrown out. Notes for 10 May include "Not excavating."

On 11 May the nuthatches were seen mating. During the nesting period trips were made to a nearby pine tree for resin which was taken to the nest tree and put on the bark around the nest hole. This area glistened in the sunlight.

Around 29 May the adults were seen

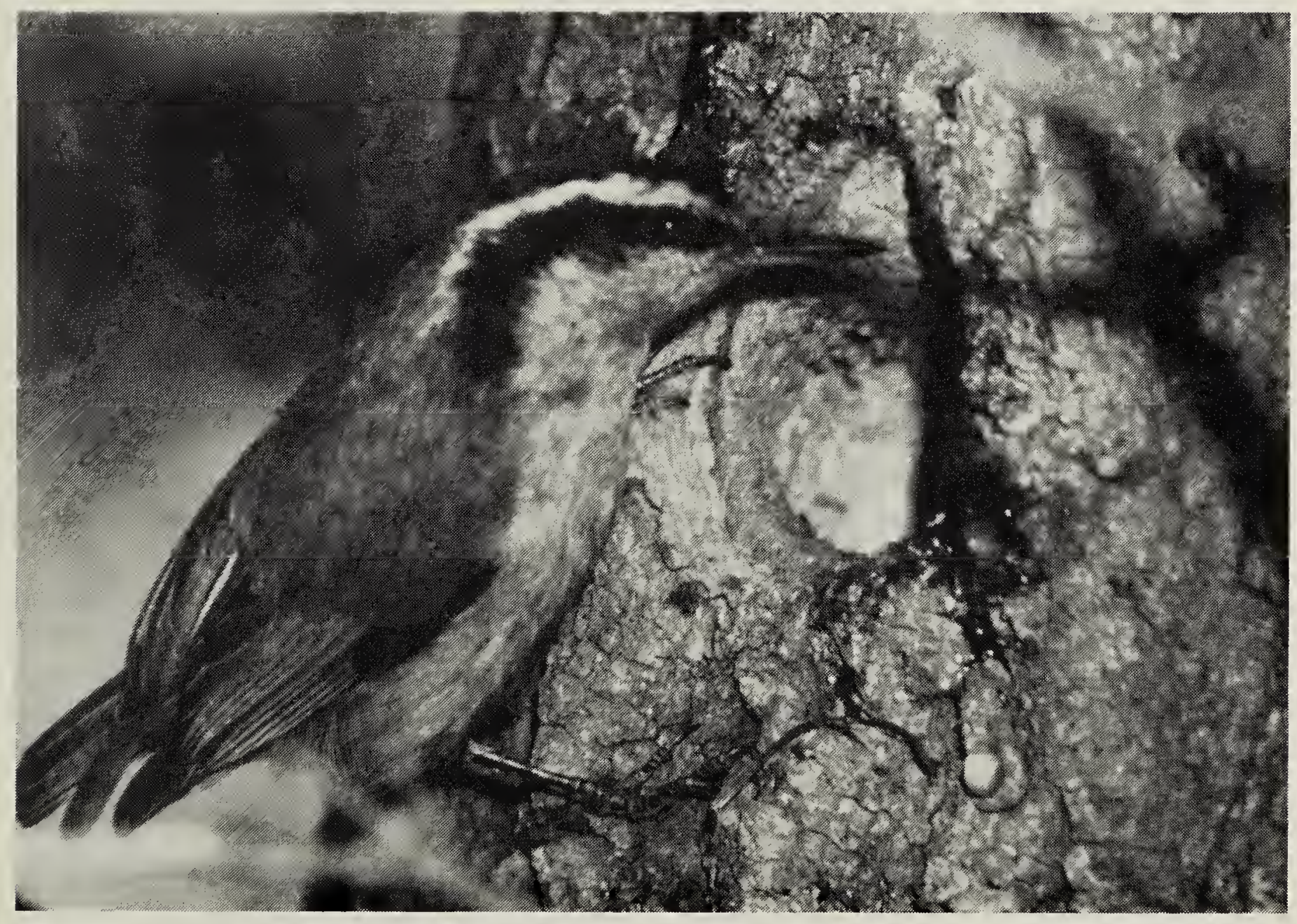

Red-breasted Nuthatch at nest at Indian Head, Saskatchewan

Lorne Scott 
carrying food. They made many trips with food, into the hole and out, and later passed food to the nestlings from the edge of the hole. They were also observed taking away fecal sacs.

On 17 June two open mouths appeared at the opening and later in the afternoon two heads. In the evening there were nuthatch sounds near the nest tree. Two young birds were seen out of the nest, another was being fed at the hole. It would appear that the latter soon left since the following morning a smaller bird was being fed there by the male adult. The other birds were not seen. The male continued coming with food, being last seen at the nest tree in the morning of 19 June.

After activity ceased at the nest tree, Red-breasted Nuthatch calls were heard regularly in the neighborhood, with occasional sightings. On 30 June four of the birds were observed at a bird bath in the yard.

Through a period of extremely hot and dry weather the pair of Red-breasted Nuthatches proved to be diligent and faithful parents.

\section{CAROLINA WREN AT LETHBRIDGE, ALBERTA}

TERESA M. DOLMAN, 37 Carleton Road W., Lethbridge, Alberta. T1K 3X4

At 6:15 a.m. on 21 August 1987, Doug Dolman and the author heard a bird singing very loudly outside the window, and it was not a "regular." The bird was soon located sitting on the porch steps. Before it flew, its wren-like appearance was noted. With binoculars, the bird was observed in the back yard, still singing, but this time giving a different call. It was rummaging around the compost bin and under a large squash plant. From there it flew again, to land in a tree about $8 \mathrm{~m}$ distant and again it sang. Although the sun had barely risen, the sky was clear and viewing conditions good. The bird was larger than a House Wren and had a conspicuous white line over the eye and a solid rufous brown back. When it flew away the field guides were consulted. By appearance, it best fit the description of either the Carolina or the Bewick's wren, and by song, the Carolina Wren. We had neither seen nor heard these two birds before. The neighbourhood was later searched with the hope of hearing the wren without luck.

At $12: 15$ p.m. the wren was again heard. A recording of the Carolina Wren song was then played on a borrowed copy of the National Geographic bird sound records. The wren was located on the property-line fence; it was agitated, scolding constantly and cocking its tail. This scolding was recorded on a portable tape recorder. At a second playback of the Carolina Wren song it flew to the sundeck 